\title{
EchoGéo
}

$43 \mid 2018$

Processus de gouvernance dans les territoires ruraux

\section{Governance in Rural Contexts: Toward the Formulation of a Conceptual Framework}

David J. Douglas

\section{(2) OpenEdition \\ Journals}

Electronic version

URL: https://journals.openedition.org/echogeo/15265

DOI: 10.4000/echogeo.15265

ISSN: 1963-1197

Publisher

Pôle de recherche pour l'organisation et la diffusion de l'information géographique (CNRS UMR 8586)

\section{Electronic reference}

David J. Douglas, "Governance in Rural Contexts: Toward the Formulation of a Conceptual

Framework", EchoGéo [Online], 43 | 2018, Online since 22 March 2018, connection on 23 August 2021.

URL: http://journals.openedition.org/echogeo/15265 ; DOI: https://doi.org/10.4000/echogeo.15265

This text was automatically generated on 23 August 2021

EchoGéo est mis à disposition selon les termes de la licence Creative Commons Attribution - Pas d'Utilisation Commerciale - Pas de Modification 4.0 International (CC BY-NC-ND) 


\title{
Governance in Rural Contexts: Toward the Formulation of a Conceptual Framework
}

\author{
David J. Douglas
}

\section{Introduction}

1 Some time ago several researchers noted the perplexing lag between the attention accorded the emergent phenomenon of governance in national and urban contexts and the same in rural contexts (e.g. Marsden and Murdoch, 1998; Goodwin, 1998). It was noted that if Jessop's "conceptual trinity" of state, market and civil society (Jessop, 1995, p. 310) no longer reflected the realities of the distribution and the exercise of power, and the roster of players at the national and even global development contexts, there was no reason to assume that it accurately reflects the functioning of institutions and power interests at the local rural level. Reassuringly some of this inattention to rural contexts has been addressed, though the gap clearly remains (Pemberton and Shaw, 2012). And during this period of inattention the driving phenomenon of governance itself has continued to differentially evolve (Chhotray and Stoker, 2008). As have the parallel factors of globalization, the so-called "hollowing out of the state", what has been called rural restructuring and other developments, all of great import to the future development options for rural communities and regions. All of this suggests the need to focus our attention on the still emerging phenomenon of governance in rural contexts. One way of contributing to this agenda is to address the over-arching question of an appropriate and potentially illuminating conceptual framework. That is what this brief essay attempts.

2 A better understanding of the changing characteristics and operating conditions of an evolving governance in rural contexts requires the development of a conceptual framework which serves to capture the integral and integrating forces and factors shaping the regional and local development climate, and the rationale(s), constraints, 
potentials, operating modalities, and other characteristics of governance in these smaller, unique and often remote contexts.

3 Simply put, a conceptual framework provides an ordered construct of assumptions, principles and rules that holds together the ideas comprising a particular concept. The purpose of a conceptual framework is not to postulate definitive cause-effect relationships, outputs or outcomes, or to prescribe any normative attributes for locally-based rural network arrangements. The purpose is to illuminate our understanding of these governance constructions and to facilitate the formulation of relevant questions for research and policy.

4 After presenting the basics of the proposed framework, the principal components of the framework will be elaborated upon, making the case for their inclusion. Then selected research, policy and development practice challenges and questions will be suggested.

\section{Toward a Conceptual Framework}

5 There are at least five major components which might contribute to the formulation of a conceptual framework for interrogating the phenomena of rural governance (Fig. 1). These include the extensive and diverse discourse on "rural" itself and the concomitant critical exploration of "rurality". The distinctive facets of rural contexts such as size, density, scale, level and distance, as well as its representation, its power dynamics, and identity all come into play here. Regardless of the final role it might play in a rural system of governance, local government must be a central consideration in any construction of a conceptual framework, notably the global trends toward functional, organizational and political restructuring. Central to any conceptual framework is of course the ongoing construction of the emergent concept of governance itself. Its fertile formulation in the work of Stoker and others has now blossomed into a diverse and perhaps diverging intellectual construction of this complex mode of power (e.g. Stoker, 1998; Jessop, 1995), its multi-stakeholder organizations, its context responsive opportunism, its power sharing and decision design. 
Figure 1 - Rural Governance - The Interrelated Conceptual Foundations

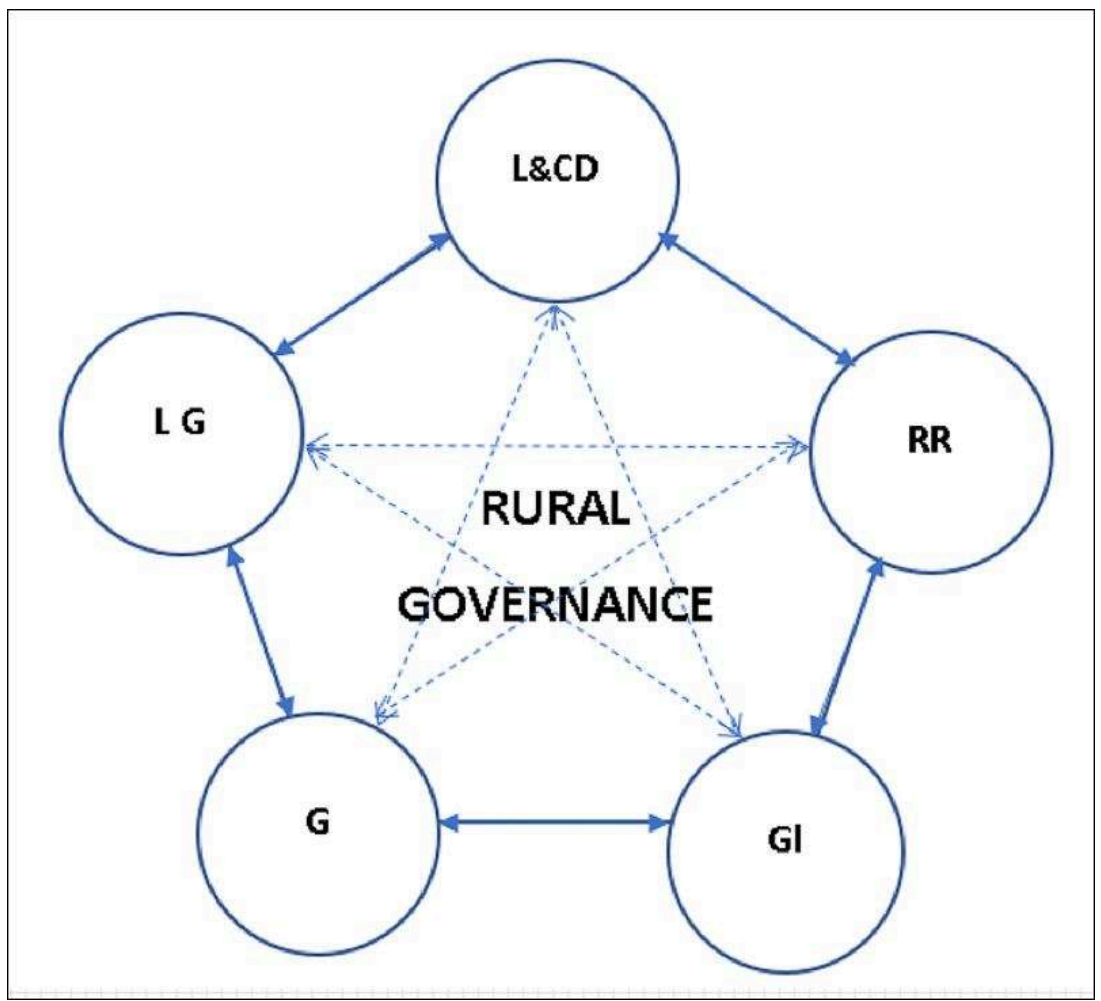

Note: L \& CD - Localism and Community Development, RR - Rural and Rural Restructuring, GI Globalization, G - Governance, LG - Local Government.

6 Not surprisingly the ongoing and somewhat amorphous discourse on globalization with its multifaceted and conflated constructions and putative implications brings something of a macro-structural membrane to any conceptual framework on rural governance. The varied presence and penetrations of such developments as neoliberalism, the unfettered dynamics of capital, the continuing stream of technological innovations and diffusions, the geopolitical role of so-called trade blocs and other global governance systems are all in play here. And now the pressing priorities associated with climate change, the calamities of international migration, and other global developments variously find their way into the local rural context.

7 And finally, the emergence of a more assertive localism, sometimes associated with an 'Alternative Economics' (e.g. Ekins, 1986; Bruyn and Meehan, 1987) and oppositional initiatives, sometimes associated with not only a growing sense of place but also placebased development (PBD), is a pivotal component in any conceptual framework here. With it we find active endogenous community development and a movement toward greater self-reliance, and perhaps the ersatz 'New Regionalism', all feeding into the complexity of rural contexts, and therefore, any construction of a conceptual framework for governance in these contexts.

8 It is posited that these five overlapping sets of concepts provide the foundational blocks for a conceptual framework to interrogate the heterogeneity and selected commonalities in rural governance systems. 


\section{The Components of the Conceptual Framework}

\section{Governance}

9 Governance can be defined as a new, negotiated, multi-stakeholder process and a collaborative system of decision design and decision making, characterized by significant degrees of self-governing, with attendant resources commitments and shared power, where there is sufficient common cause and a pragmatic understanding that to achieve the requisite capacity and agency requires appropriate institutional and organizational arrangements beyond the established architecture of power, control and authority, notably that of government (Douglas, 2006). As with the other components of this posited conceptual framework, we cannot delve into the rich, voluminous and sometimes contested discourse that attends this particular component (Jessop, 1995; Rhodes, 1996, 1997; Stoker, 1998; Pierre, 2000; Veselý, 2004; Aarstaeher et al., 2008).

However, common among the great diversity of initiatives to conceptualize the essence of governance and its evolution is to see governance as an emerging strategy by the beleaguered liberal-democratic state, in some retreat from neo-liberalism and all its trappings, as it attempts to redefine its role and relevance (e.g. Pierre, 2000, p. 2), notably its authority and remit. With or against this perspective is one which sees governance as a collection of forces from below (i.e. locally) and above (i.e. supranationally) and from the market, all set within the post-Fordist realities of advanced capitalism. These combine to cumulatively re-cast the political topography. This still emergent construction, after the "hollowing out" of the former command and control state (Jessop, 2013), manifests itself in its variety as networked combinations of relatively autonomous self-governing organizations spawned by central and other governments to do the work of governing, but collaborating with the private sector (e.g. in PPPs), with a diversity of NGOs (e.g. heritage, conservation, social justice ) and other civil society organizations, with local authorities, and occasionally with international organizations.

11 The driver in all of this is the shared imperative to attain agency, which is not sufficiently available to the individual participants. The need is to influence and steer a chosen course of direction where there is common interest, but where the capacity and other resources to do so requires collaboration. Governance pragmatically either supplants or dramatically dilutes government governing. Scare resources are pooled, the operational domain of formal authorities is re-negotiated for the task at hand. "Steering" and "rowing" mandates are negotiated. Leverage and efficacy are central considerations. Legitimacy is pursued through challenging initiatives in transparency and accountability in the opportunistically constructed organizational and institutional arrangements. A common thread is that of oftentimes informal organizations and networks (sometimes self-organizing) undertaking roles and functions that were previously associated with formal government. Inherently processes of evolution, learning, trial and error, experimentation, opportunism, emulation and adaptation are integral to most governance systems. To a significant extent, as they are contextually constructed, they are situationally organic.

12 Perhaps we should not be surprised to hear the term "new magistry" applied to this variegated and still emergent political economic landscape. Likewise, we have to live with the reality that the term "governance" is used with endless license and not a little 
confusion, notably by politicians, the media and others, including development organizations (e.g. UNDP, 2014).

Besides its spatial endogeneity, it is because of its emergent, nascent and uncertain configuration that the concept of governance itself should be seen as a logical component in any conceptual framework for rural governance. Its situational construction, its contextual reflexivity and responsiveness suggest important interrelationships with place-based development, endogenous process, the contested co-production of power and other elements of the conceptual components of this suggested framework.

\section{Rural}

The characteristics of rural contexts (e.g. landscapes, communities, organizations) are both operable in governance systems as active subjects (e.g. resident groups, land owners) and as objects being acted upon by various forces (e.g. pension funds, local authorities). But either as subjects or objects the characteristics associated with being rural are fundamentally important when interpreting current systems of governance or considering the designing of governance systems, the efficacy of these arrangements, and the anticipated cause-effect relationships in the development process. The literature on being rural and the condition of "rurality" is voluminous (e.g. Newby, 1980, 1986; Douglas, 1989, 2010a; du Plessis et al., 2001; McDonagh, 2001; Moseley, 2003; Reimer, 2005; Woods, 2005; Cloke, 2007; Reimer and Bollman, 2010). Across most of this the centrality of size, density and distance are universal considerations with myriad implications. These and other core characteristics of being rural mean that rural communities will have small, often fragile, open, and very often resource-based economies, with an array of attendant vulnerabilities and other implications. Health, education and social services provision will be truncated, and much of these have to be accessed elsewhere, at some distance and cost. Local government, where it exists, will be small, have a narrow service role (e.g. local roads, waste collection) and a modest resource base, particularly in own-source revenues (Douglas, 2016). The demographics of most rural communities, with the obvious exceptions (e.g. commuter towns, active mining centres) will consist of small populations with "wasted" profiles, with the attendant implications on service needs, markets, economic potentials and other issues. In more rural remote contexts issues around Indigenous populations bring with them an additional set of challenges (e.g. Norway, Canada). Then there are factors of culture, traditions, identity and other considerations bearing on a long established and often cherished way of life, innovation, absorptive capacities, politics, government and governing, and sustainability itself. Generating a critical and informed understanding of governance in rural contexts must explicitly incorporate the unique realities of rural. The sharing of power, the establishment of network organizations, the collaborative pooling of scarce resources, the insertion of self-governing and largely autonomous governmental agencies, increased roles for public-private partnerships, and other cornerstones of governance-type arrangements have to be negotiated and mediated through the realities of rural contexts, which are in stark contrast to most urban settings.

The differentiated and highly contested processes of what has been called rural restructuring, evident in many though not all developed contexts, brings an added 
complexity to the realities of rural communities when we address issues of governance. As with the question of "rural" there is a considerable body of research and critical commentary around this variegated phenomenon, especially in the last three decades (e.g. Woods, 2005; Cloke et al., 2006). While the rural restructuring discourse encompasses a breadth of issues relating to a post-productivist and post-Fordist and even post-modern perspectives, a central theme appears to be a broad reconceptualizing of what "rural" and "rurality" are all about, and becoming. Set within the complex processes of rural restructuring governance as a collaborative intervention increasingly must function within a variety of "landscape occupance modes" (Holmes, 2002), where the new forms of consumption vie with established practices and production relationships of food, fibre and mineral resources production and associated priorities. Consumption manifested in heritage preservation, second home building, arts and cultural installations, equestrian activities, walking and hiking infrastructure, speculative investments in land and a host of other interventions brings with it at times dramatic social, cultural, environmental and political repercussions. These may range from entirely new representations of the "rural" itself (e.g. Nilsson and Lundgren, 2015), novel valuations of what constitute rural "resources", external and often very distant power interests (e.g. energy investors) and decision making, and organizational change, to a cumulative re-casting of the local economy, the supplanting of traditional leadership within the community, shifting power relationships within the rural community's long established organizations, including local government, and others. Not unexpectedly rural restructuring is sometimes associated with friction, divisive opposition, distress regarding the anticipated loss of traditional agrarian and other rural values and ways of life, and hostility with the incursion of external and often faceless interests and agendas. The overlaps with globalization and community development are self-evident. Complex interrelationships between rural restructuring and any initiatives in a negotiated local collaboration involving shared power, pooled resources, organizational design, and a mediated role for government(s), are also to be expected. As with the other four components in this conceptual framework, the nature of the interrelationships will be contextually and situationally determined.

\section{Globalization}

The daunting breadth and amorphous nature of globalization and its uncertain trajectory (e.g. Dicken, 2003; Roberts and Hite, 2003; Woods and McDonagh, 2011) might suggest that it has the potential to overwhelm or at least dominate any and all rural governance projects. However, we have learned that the revealed presence of globalization and the nature of its penetration into the rural realm is selective, and as briefly discussed here, there is something of a countervailing project in localism and community self-determination that appears to be bent on tempering the presence of this potentially hegemonic force. Having said that, several of the received markers of globalization, such as international governance institutions (e.g. World Bank, IPCC, ECB), the permissive agenda and dynamics of borderless capital, trade blocs (e.g. NAFTA, CEETA) and others are increasingly evident in rural regions. They have and continue both to circumscribe the development options for rural regions, while at the same time intervening directly in the resource allocation and other priorities of rural communities through, for example, corporate water taking, PPP projects, seasonal labour migration programs, resource infrastructure investments, land purchases, and 
many other interventions. The direct implications of globalization are explicitly stated as formative factors in Ireland's forthcoming national spatial development strategy, and a major consideration in rural development (Ireland, 2017).

\section{Local Government}

It might seem tautological to assert that formal local government could directly influence the governance constructs and their operations in rural contexts, but given the popular confusion between government and governance, the institutional conditions of local government deserve explicit attention. This is so because local government may be entirely absent, play a very minor role, or take the lead in area governance arrangements. These various presences may be explicitly evident or be far less visible through implicit or tacit understandings and informal practices. In addition, the centre's design for its local authorities and the delegation or devolution of roles and functions, with associated resources, varies very significantly from place to place (e.g. Herve, 2007). On top of this the global patterns of local government "reform" and restructuring are also extremely diverse (Douglas, 2016), creating very different operating conditions for both local government (where it exists) and any local governance systems. So not only do different rural local governments have very different roles and responsibilities and attendant resources, such as those in the highly centralized Irish system (e.g. Breathnach, 2014) versus those in the highly devolved and autonomous Norwegian system, but the restructuring agenda varies dramatically from place to place, such as in the devolutionary and progressive municipalité régionale de comté (MRC) system in Québec, Canada, versus the highly fragmented Hungarian system (Douglas, 2016). Local government restructuring may, in some contexts, be found to be antithetical to rural development (Douglas, 2005).

18 So, the breadth and depth of the remit that local government is accorded by, or won from central governments will either constrain or facilitate the extent and nature of its engagement with civil society organizations and the private sector, as well as other levels of government, in any local governance arrangements. With limited resources and a narrow services mandate (e.g. basic public works, building permits) local government may be a limited and relatively lightweight player, with a very circumscribed "rowing" function, if any. In contrast, with diverse and resilient resources, such as income tax, and an extensive portfolio of delegated or devolved services (e.g. economic development, housing, welfare) local government has the potential to be a major partner. In addition, the ideological and value underpinnings of the local government system will influence the autonomy or otherwise of this level of government, the legitimacy of its role choices, its comfort with the NGO sector and community activism, and its fit within opportunistic shared power constructions.

\section{Localism and Community Development}

While community development (CD) as a process pursued through relational complexes (Douglas, 2010b) itself subsumes so much that is associated with governance, one can visualize the multifaceted process of community development as a foundational concept underpinning any and all local governance systems (Douglas, 1993). Governance constructs by definition are purposeful designs to achieve certain desired outputs (e.g. inter-agency coordination, project legitimation) for desired outcomes (e.g. 
a healthier community, economic diversification), so some of the theoretical underpinnings of $\mathrm{CD}$ such as its teleological roots (Bhattacharyya, 2004) intermesh with those informing governance systems. The same core agenda of solidarity and agency (Ibid., 2004) in local and community process is usually shared. Likewise, the attention to what has been referred to as agents, agendas, activities and arenas (Douglas, 1994) may be used as a shared conceptual scaffolding. Besides these conceptual commonalities, the fundamental principles relating to such things as social justice, distributional welfare, participation, access and voice, transparency and accountability, local democracy, self-reliance, endogenous process, and several others overlap community development and rural local governance systems.

But perhaps the pivotal linkage between community development and local governance systems is what has been called a renewed interest and investment in localism (e.g. Cox, 2011). Our appreciation and understanding of the rural community qua community has undergone something of a renaissance. Whether this has been fueled by the relentless attention to globalization and the associated concerns of hegemony and a new colonization is a moot point. What is of interest here is that this renewed attention to bottom-up or endogenous process has incorporated potent theoretical developments in social capitals (e.g. Gittell and Vidal 1998; Woolcock, 2001; Reimer et al., 2008), capacity building (e.g. Connell, 2004), and governance itself, eventually generating the promising concept of place-based development (Markey, 2011; Markey et al., 2012; Douglas, 2013; Daniels et al., 2015). Place is increasingly appreciated as an active ingredient in the development process, not a passive dependent recipient of sectoral and centre-sourced investments and directives. It is a complex of unique assets (e.g. Pecqueur, 2013), such as leadership, solidarity or entrepreneurialism, producing its own competitive advantage. Some of the more unique or "specific assets" will be those that are discovered by the community, and that result from a long cognitive and social process producing unique know-how in the community, and an array of collective goods (Ibid., 2013). All of this reconstituting the endogenous dynamism and potency of place has led to a comprehensive reconsidering of the conventional wisdom in rural development, as exemplified in the New Rural Paradigm (OECD, 2006).

21 Drawing upon several sources Hess and Adams purport that "the link between governance models and the likelihood of place-focused policies succeeding in particular areas was noted a characteristic of this trend by European commentators" (Hess and Adams, 2007, p. 41). They note the non-positivistic and pro-constructivist approach to community strengthening that their research, and that of others suggests. The epistemological basis of community strengthening policy is therefore challenged, as knowledge is created from the in-community experiences and development episodes. One might note the connection to Social Learning theory in the development planning context (Freidmann, 1987). Moving from the expert driven approach and the approach which searched for imported solutions and practices to the "problems" as described, there is "an active search for new interpretive ideas and instruments" (p. 48) because they will reflect more efficaciously the experiences of particular policy communities. In order to address the non-linear place particular complexities, a participatory constructivist and non-rational approach is found to be much more appropriate. This is an extremely relevant conclusion, confirming as it does much of the received theory 
and practice in community development. It has a direct bearing on the formulation of a conceptual framework for rural community governance.

These and other researchers have noted that the global and long term evidence that strengthening communities has multiple longer term and broad-based benefits. Higher participation rates, denser networks, strong, active organizations, skilled distributed leadership, greater connectivity and so on serve to reduce school drop-out rates, imprisonment rates, crime, homelessness, and so on, while extending longevity, reducing childhood illness, and more. Community development pays off. And there is a direct link in community strengthening investments, the development of the community and the commitments to fostering governance.

The participatory dimension of community development is almost a tautological entity as it is by now more than self-evident that engagement of the community's residents is a sine qua non for community development, both in terms of requisite process and as a tangible manifestation of desirable outcomes, or evidence of effect. Stoker and many others have stressed the fundamental characteristic of participation in the emergent topographies of governance. And a variety of governments have long acknowledged the centrality of public participation in the rural development process (e.g. Welsh Office, 1996). So, participation, community development, rural development and governance are all inextricably intertwined.

\section{Discussion and Selected Challenges}

24 As already noted, part of the conjunction suggested here was proffered by Marsden and Murdoch as long ago as 1998 (Marsden and Murdoch, 1998). Goodwin has articulated the intersections of the emergent governance and the decline of the post-War Keynesian welfare state, the reconstituting of rural societies, economies and landscapes as multi-functional entities, and the concomitant waning of the hegemony of agrarian interests. Into this we have had the reconfiguration of central government and the proliferation of quangos and decentralized service agencies, some largely autonomous and self-governing, delivering assorted government services emanating from the centre. And then the emergence of a great variety of local and regional organizations through the EU (e.g. LEADER) and others sources (Goodwin, 1998). The shifting relationships between globalization and its uncertain footprints in rural regions, political decentralizations, privatization and other elements of rural restructuring and rural institutional capacities and rural regional governance have also been addressed (e.g. Morrison, 2014). So, several elements of the conceptual framework explored here have been in the mix for some time.

At a conceptual level the complex of interrelationships, cross-impacts, feedback processes and more that are posited in this framework can be convincingly argued. For example, rural governance systems will be responsive to and in turn will influence the nature of local leadership, the cultural imagining of "community" among local residents, and the processes of local power relationships and the reproduction of power. Likewise with the formal authorities and responsibilities, with attendant resources and leverage, that are to be found in local government. The ongoing processes of rural restructuring and the attendant manifestations of internal and external vested interests in land, in landscapes, in alliances and networks will avail of the market and its institutional resources to underpin their agendas and priorities. 
Some of this will be pursued through the dynamics of rural governance. The "strategic line" of central government, indeed of supra-national interests will intersect with the rural community's co-construction of governance systems. These in turn will be influenced by and will influence the viability of a place-based approach to local development, and the community's fundamental social solidarity and its sense of agency. So, the multi-directional formative and responsive interrelationships among these conceptual components to the rural governance system can be argued. The specific nature of these cause-effect and associative relationships, and their recursive and cumulative systems theoretic dynamics is another question.

Might governance at the very local rural level overcome Stoker's concerns that it will "lack the simplifying legitimizing 'myths' of traditional perspectives such as the British Wesminster model." (Stoker, 1998, p. 24)? It could be argued that at the local level the depth of traditional modes of operating and decision making, the known and understood roles of community and local organizations, the fixity, the inertia of institutional structures and rules, embedded "truths" and norms, and the tacit influence of macro-structures and systems will cumulatively provide the rural community with its legitimizing 'myths'. And these perspectives would be integral to the components of the conceptual framework suggested here. In fact, in combination the interplay of long established community relationships and newly constituted local governance practices may make for a socially constructed "structural coherence" as unique time-space entities for rural contexts (Harvey, 1985).

Is the emergent system of governance in rural milieux to been seen as the antipode of the upward and outward movement of formal power and authority (away from the nation state) toward supra-national governance entities (e.g. the EU, NAFTA), transnational corporations, so-called fintech and related global sectors that populate Davos and other arenas, global non-government interest organizations (e.g. World Wildlife Fund, Greenpeace), and others? As already noted, global forces do selectively penetrate rural contexts (e.g. Nestlés in rural Ontario). And we are increasingly aware of the fact that rural regions function as distinct economic spaces in the increasingly open, global economy. This has been one of the footings for the ersatz New Regionalism (MacLeod, 2001; Markey, 2011; Daniels, et al 2018). Global accumulation and reproduction priorities and strategies get played out in regional economies and sociopolitical systems. Thus, local democracy and accountability are being taxed in these new challenges to established political systems. Conceptualizing rural governance has to be addressed within these emergent realities.

Related to the above, the need to attend to the investment in and support of collective agency in rural governance arrangements has been strongly argued. A more sensitive, nuanced and reflexive approach is advocated through "learning regions" and purposeful support by the public sector to ensure that local governance processes do in fact enable local residents to fully engage in the place-based development process (Wellbrock et al., 2013).

29 Viewing local governance in rural contexts within the broad discourse of neoinstitutionalism (Peters, 2012) might draw our attention to (1) the rational perspective of rules and incentives, the centrality of efficiency and other concepts imported from Economics, and the contest for (re)writing the rules and the acquisition of leverage, (2) the more constructivist sociological perspectives with the cultural construction of institutions with associated norms, rules, sanctions, structures and then myths, 
cognitive scripts, moral templates, symbols and ceremony and ritual, where the singular efficiency and related metrics become blurred or replaced, and (3) the more historical perspective addressing path dependency. The conceptual framework outlined here in no way answers the challenge of either choosing among these, or balancing them as competing interpretive schemes. But through the five component concepts it facilitates the critical engagement of these perspectives.

One notes the centrality of legitimacy in governance, and its potentials at the very local rural community level. Following Beetham (from Stoker, 1998), the three axes underpinning any legitimacy are conformity to understood and established rules, the justification of these rules through their grounding in commonly shared beliefs, and the expressed consent of the subordinates, or the most significant among them to the particular relations of power that the governance systems introduces, advocates and seeks to perpetuate. One is cautioned that localism does not necessarily engender legitimacy in the shared development narrative (Molden et al., 2017). The explicit cultural and sociological underpinnings of community development in the conceptual framework would allow for a concrete incorporation of these important perspectives.

31 Following Rhodes (1996) we are reminded of the complex tension fields involving, among many other things, the press for authoritative action and the concomitant dependency on the willing compliance and action of others. And one notes that this is made even more complex by the shifting resources contributions by participants, the profile of these resource types (e.g. personnel, territory, legal access), the inertia of embedded protocols and rules, the gradients of risk tolerance and aversion among the participants, the differentials in constituency legitimacy across the participants, the diversity of accountability expectations across participants, and so on. It is daunting, bringing to mind Foucault's concept of "governmentality", referring to the way the state or any powerful entity devises ways and means to exert control over the conduct or behaviours of its population, groups, organizations, individuals and others. But it also addresses how people are taught to exercise control over themselves. How do rural residents learn to govern their own conduct? How is this conduct shaped? This takes us to the centre of the conceptual framework and the pivotal issues of socialization, power and the reproduction of power relationships, and the associated issue of regulation, sanctions and coercion.

Not only does the posited conceptual framework outlined here have several antecedents in terms of its constituent concepts, the logical architecture has some antecedents. The focus on complex webs of interrelationships and communications processes, with the question of power at the centre of all of this connects very clearly with Bryson and Crosby's concept of forums, arenas and courts (1996). The emphasis on notions of decision design, decision making and taking connects with Douglas's conceptualization of agents, agendas, activities and arenas applied to the community development process (1994).

Some further questions and challenges that any conceptual framework here will have to address include the following:

- Is the well-worn call for local autonomy now redundant in the context of multi-partner and multi-level governance arrangements, where both power and authority are variously placed outside of the immediate realm of the rural community itself?

-Where does "game playing" come into all of this? Do the explicit or implicit understandings in governance suggest a willingness to cope with the open-endedness and uncertainty here? 
- Where does the concept of "regime" and its potential roles in local rural governance systems become integrated in any conceptual framework (Stoker, 1998, p. 23)? Under what conditions are regimes as regulators or custodians of order likely to form in smaller rural contexts? How do particular negotiated roles and norms become robust and embedded? How do they become less stable, uncertain, contested in the context of common pool resources (Ostrom, 1990)?

-What about the intrinsic exclusivity of local networks? Does this suggest particular characteristics or ways of operating? Does it constrain their viability, their accountability or legitimacy? And from this are locally based rural governance arrangements antithetical to "systems transformation", without which many would not see any credible rural development (Freidmann, 1987)?

- Does a local rural community working through a complex of self-organizing networks - on trust, reciprocity, cooperation, gaming dynamics, negotiated interdependencies, resource sharing, rules, order, exchange, common goals, operating protocols, and other relationships - have the requisite capacity to deal with an external system that is primarily functioning on a contractual market-based system and a system of formal, if largely regulatory hierarchical bureaucracies? Or are there two incompatible operating systems confronting an impossible interface?

These and others are demanding challenges for any robust conceptual framework for rural governance. The permissive breadth in the posited framework outlined here provides some promise in digesting the diversity of questions and challenges raised. But until refined and tested, these questions and others remain.

\section{BIBLIOGRAPHY}

Aarstaeher N., Roiseland A. and Jenssen S. (eds.), 2008. Practicing Local Governance: Northern Perspectives. Nova Science Publishers, Hauppage, New York.

Beetham D., 1991. Legitimation. London, Macmillan.

Bhattacharyya J., 2004. Theorizing community development. Journal of the Community Development Society, vol. $34, \mathrm{n}^{\circ} 2$, p. 5-34.

Breathnach P., 2014. Creating city-region governance structures in a dysfunctional polity: The case of Ireland's National Spatial Strategy. Urban Studies, vol. 51, nº 11, p. 2267-2284.

Bruyn S.T., Meehan J., 1987. Beyond the Market and the State: New Directions in Community Development. Philadelphia, Temple University Press.

Bryson J.M., Crosby B.C., 1996. Planning and the design and use of forums, arenas, and courts. In Mandelbaum S., Mazza L. and Burchell R.W. (eds.), Explorations in Planning Theory. New Brunswick, NJ; Rutgers University, chap. 22. p. 462-482.

Chhotray V., Stoker G., 2008. Governance Theory: A Cross-Disciplinary Approach. London, Palgrave Macmillan.

Cloke P., Marsden T.K. and Mooney P.H. (eds.), 2006. Handbook of Rural Studies. London, Sage. 
Cloke P., 2007. An index of rurality for England and Wales. Journal of Regional Studies, vol. 11, $\mathrm{n}^{\circ} 1$, p. 31-46.

Connell D., 2004. Economic Capacity Profiles: 2004 Update. Montreal, Concordia University. http:// nre.concordia.ca/capacity_profiles_2004.htm, accessed January 2017.

Cox K.R., 2011. Institutional geographies and local economic development: Policies and politics. In Pike A., Rodríguez-Pose A. and Tomaney J. (eds.), Handbook of Local and Regional Development. London, Routledge, chap. 23. p. 272-282.

Daniels J., Baldacchino G. and Vodden K., 2015. “The making of place and identity.” In, K. Vodden, R. Gibson, and G. Baldacchino. (eds.). Place Peripheral: Place-Based Development in Rural, Island and Remote Region. St. John's, NL: ISER, Memorial University of Newfoundland. Chap. 2. pp. 23-40.

Daniels J., Douglas D.J.A., Vodden K. and Markey S., 2018 (Forthcoming). New Regionalism. In Vodden K., Douglas D.J.A., Reimer B, Markey S. and Minnes S (eds.), The Theory, Practice and Potential of Regional Development: The Case of Canada. London, Routledge, chap. 3.

Dicken P., 2003. Global Shift: Reshaping the Global Economic Map in the 21st Century. New York, Guilford Press.

Douglas D.J.A., 1989. Note from the Guest Editor. Plan Canada, vol. 29, n², p. 3-7.

Douglas, D.J.A. 1993. Community Development: Observations and Lessons from Experience. Guelph, Rural Reportings, University School of Rural Planning and Development, University of Guelph.

Douglas, D.J.A., 1994. Community Economic Development in Canada. Toronto, McGraw-Hill Ryerson, vol. 1.

Douglas D.J.A., 2005. The restructuring of local government in rural regions: A rural development perspective. Journal of Rural Studies, vol. 21, p. 231-246.

Douglas D.J.A., 2006. Getting the Goods on Governance. Guelph, Presentation to the Outlook Conference, Ontario Ministry of Agriculture, Food and Rural Affairs.

Douglas D.J.A. 2010a. Introduction. In Douglas D.J.A. (ed.), Rural Planning and Development in Canada. Toronto, Nelson. p. 2-9.

Douglas D.J.A. 2010b. Community development: A cornerstone of rural planning and development. In Douglas D. J.A. (ed.), Rural Planning and Development in Canada. Toronto, Nelson, chap. 10. p. 281-327.

Douglas D.J.A., 2013. Place making: An antidote for the endemic case making. Ottawa, Opinion, Canadian Rural Research Network.

Douglas D.J.A., 2016. Power and politics in the changing structures of rural local government. In Shucksmith M. and Brown D.L. (eds.), Routledge International Handbook of Rural Studies. London, Routledge, chap. 50, p. 601-614.

Du Plessis V., Beshiri R., Bollman R.D. and Clemenson H., 2001. Definitions of "Rural”. Ottawa, Rural and Small Town Canada Analysis Bulletin, vol. 31, $n^{\circ}$ 3, Statistics Canada.

Ekins P. (ed.), 1986. The Living Economy: A New Economics in the Making. London, Routledge.

Gittell R., Vidal A., 1998. Community Organizing: Building Social Capital as a Development Strategy. Thousand Oaks, Sage.

Goodwin M., 1998. The governance of rural areas: Some emerging research issues and agendas. Journal of Rural Studies, vol. 14, n 1, p. 5-12. 
Harvey D., 1985. The Urbanization of Capital. Oxford, Blackwell.

Herve M., 2007. Government or governance? The case of the French local political system. Western European Politics, vol. 21, n 3, p. 146-169.

Hess M., Adams D., 2007. Governance and community strengthening. In Osborne M., Sankey K. and Wilson B. (Eds.), Social Capital, Lifelong Learning and the Management of Place. London, Routledge, chap. 4, p. 41-50.

Holmes J., 2002. Diversity and change in Australia's rangelands: a post-productivist transition with a difference? Transactions of the Institute of British Geographers, vol. 27, p. 362-384.

Ireland, Government of, 2017. Ireland 2040: Our Plan. Dublin, Department of Housing, Planning, Community and Local Government.

Jessop B., 1995. The regulation approach and governance theory: Alternative perspectives on economic and political change. Economy and Society, vol. 24, n 3. p. 307-333.

Jessop B., 2013. Hollowing out the 'nation state' and multi-level governance. In Kennett P. (ed.), A Handbook of Comparative Social Policy. Cheltenham; Edward Elgar, chap. 1, p. 11-26.

Kohane R., Ostrom E. (eds.), 1995. Local Commons and Global Interdependence. London; Sage.

Markey S., 2011. A Primer on New Regionalism. Corner Brook, NL, Working Document CRD - 4 for the project, Canadian Regional Development: A Critical Review of Theory, Practice, and Potentials.

Markey S., Hasleth G. and Manson D.. 2012. Investing in place: Economic Renewal in Northern British Columbia. Vancouver, UBC Press.

Marsden T., Murdoch J., 1998. Editorial: The shifting nature of rural governance and community participation. Journal of Rural Studies, vol. 14, $\mathrm{n}^{\circ} 1$, p. 1-4.

MacLeod G., 2001. New regionalism reconsidered: Globalization and the remaking of political economic space. International Journal of Urban and Regional Research, vol. 25, n 4, p. 804-829.

McDonagh J., 2001. Renegotiating Rural Development in Ireland. Aldershot, Ashgate Press.

Molden O., Abrams J., Davis E.J. and Moseley C., 2017. Beyond localism: The micropolitics of local legitimacy in a community-based organization. Journal of Rural Studies, vol. 50, n 1, p. 60-69.

Morrison T.H., 2014. Developing a regional governance index: The institutional potential of rural regions. Journal of Rural Studies, vol. 35, p. 101-111.

Nilsson B., Lundgren A.S., 2015. Logics of rurality: Political rhetoric about the Swedish North. Journal of Rural Studies, vol. 37, p. 85-95.

Ostrom E. 1990. Governing the Commons: The Evolution of Institutions for Collective Actions. Cambridge, Cambridge University Press.

Peters B.G., 2012. Institutional Theory in Political Science: The New Institutionalism. New York, Bloomsbury.

Pemberton S. Shaw D., 2012. Governance and implications for rural areas; Evidence from England. Planning Practice \& Research, vol. 27, n 4, p. 441-458.

Pecqueur B., 2013. Territorial development: A new approach to development processes for the economies of the developing countries. INTERthesis, vol. 10, $\mathrm{n}^{\circ} 2, \mathrm{p} .8-32$.

Pierre J. (ed.), 2000. Debating Governance: Authority, Steering and Democracy. Oxford, Oxford University Press. 
Reimer B., 2005. Rural and urban: Differences and common ground. In Hiller H.H. (ed.), Urban Canada: Sociological Perspectives. Don Mills, Toronto, Oxford University Press, chap. 2, p. 70-94.

Reimer B., Lyons T., Ferguson N. and Polanco G., 2008. Social capital as social relations: The contribution of normative structures. The Sociological Review, vol. 56, vol. 2. p. 256-274.

Reimer B., Bollman R.D., 2010. Understanding rural Canada: Implications for rural development policy and rural planning policy. In Douglas D.J.A. (ed.), Rural Planning and Development in Canada. Toronto, Nelson, chap. 1. p. 10-52.

Rhodes R.A.W., 1996. The new governance: Governing without government. Political Studies, vol. XLIV, p. 652-667.

Rhodes R.A.W., 1997. Understanding Governance. Buckingham, Open University Press.

Roberts J.T., Hite A. (eds.), 2003. From Modernization to Globalization: Perspective on Development and Social Change. Oxford, Blackwell.

Stoker G., 1998. Governance as theory: Five Propositions. Oxford, UNESCO, Blackwell.

UNDP, 2014. Governance for Sustainable Development: Integrating Governance in the Post-2015 Development Framework. New York, Discussion Paper, United Nations Development Programme.

Veselý A., 2004. Governance as a multidimensional concept. In Potůček M., Veselý A. and Nekola M., Understanding Governance: Theory, Measurement and Practice. Praha, UK FSV CESES. p. 11-22.

Wellbrock W., Roep D., Mahon M., Kairyte E., Nienaber B., Dominguez Garcia M. D., Kriszan M. and Farrell M., 2013. Arranging public support to unfold collaborative modes of governance in rural areas. Journal of Rural Studies, vol. 32. p. 420-429.

Welsh Office, 1996. A Working Countryside for Wales. Cardiff; HMSO.

Woods M., 2005. Rural Geography: Processes, Responses and Experiences in Rural Restructuring. London, Sage.

Woods M., McDonagh J., 2011. Rural Europe and the world: globalization and rural development. Editorial, European Countryside, vol. 3. p. 153-163.

Woolcock M., 2001. The place of social capital in understanding social and economic outcomes. ISUMA Canadian Journal of Policy Research, vol. 2, $\mathrm{n}^{\circ}$ 1, p. 1-17. Retrieved from http:www.oecd.org/ dataoecd/5/13/1824913.pdf

\section{INDEX}

Subjects: Sur le Champ - Sur le Terrain

\section{AUTHOR}

\section{DAVID J. DOUGLAS}

David Douglas, djdougla@uoguelph.ca, est Professeur émérite, School of Environmental Design and Rural Development, University of Guelph, Guelph, Ontario, Canada. Il a publié récemment : - Douglas D. J. A., 2017. Community resilience: Critical reflections from the Canadian rural development perspective. In Gibson L. \& R. (eds.), From black horses to white steeds: Building community resilience. Brinklow, Charlottetown, PE: Island Studies Press, p. 10-30.

- Douglas D. J. A., 2016. Roots, regions and radical practice: Rural communities in societal survival 
and transformation. In Halström, L. K., Beckie, Mary A., Hvenegaard, Glen T., and Karsten Mündel (eds), Taking the Next Steps; Sustainability Planning and Collaboration in Rural Canada. Edmonton, University of Alberta Press, Chapter 1.

- Douglas D. J. A., 2016. Power and politics in the changing structures of rural local government. In Shucksmith M. \& D.L. Brown (eds.), Routledge International Handbook of Rural Studies. London; Routledge, Chapter 50. 